\title{
SEASONAL AND ANNUAL VARIATION IN PASTURE PRODUCTION IN CANTERBURY AND NORTH OTAGO
}

\author{
K. F. O'Connor, E. W. Vartha, R. A. Blcher \\ Grasslands Division, D.S.I.R., Lincoln \\ J. D. Coulter \\ New Zealand Meteorological Service, Wellington
}

PASTURES vary greatly in production from place to place, from season to season and from year to year. In this re view of grasslands research in Canterbury and North Otago, the intention is to emphasize these variations and to identify some of the factors associated with such variations. In particular, it is intended to illustrate the relationships between production of clover-based pastures and lucerne-based pastures and seasonal factors, especially rainfall.

\section{CLOVER-BASED PASTURES}

\section{Seasonat. Variation at Lincoln}

The pattern of seasonal herbage yield at Lincoln from pastures principally of Ruanui ryegrass and Huia white clover is illustrated in Fig. 1, compiled from Grasslands Division records from 1950 to 1964 for pastures of two to five years of age on Wakanui soils, under rotation1 hard grazing. Although drought may affect pasture production in Canterbury, irrigated pastures of similar composition at Winchmore (cf. Rickard, 1968) and unirrigated pastures in North Island localities less subject to drought than Canterbury show similar seasonal patterns to that observed at Lincoln (O'Connor and Vartha, 1968). The basic pattern of spring-early summer peak of pasture production for the pasture species commonly used in New Zealand is determined by the inherent characters of the grasses and clovers themselves' as expounded by Mitchell (1956), Brougham (1959) and Campbell (1964). Within that basic pattern, weather conditions may influence the actual achievement as illustrated by Brougham (1959). 


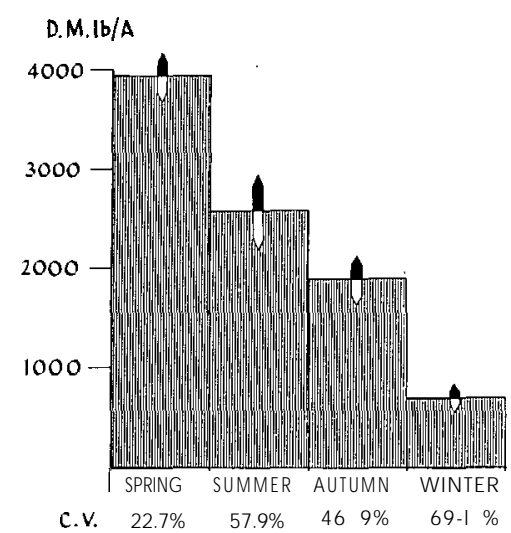

FIG. 1: Mean seasonal herbage yield al Lincoln from Ruanui ryegrassHuia white clover pastures, 1950-64, showing stundard errors for seasons. (Mean annual yield $=9,068 \pm 764$ lb D.M./acre.)

The outstanding seasonal feature in Canterbury pasture production is the winter limitation of light, heat and available nitrogen under turf. With these environmental factors is allied a comparative lack of cool-season activity in traditional plants of perennial pastures. From Fig. 1 it is calculated that less than $8 \%$ of mean annual production at Lincoln occurs during the months of June, July and August. Even this small amount is very unreliable except from newly-sown pastures in fertile ground.

Summer and autumn pasture production are also subject to great variability, as shown in Fig. 1. Spring production is not only the largest but also the most constant component of annual yield. Rainfall records for the period indicate that spring precipitation was not heavier or obviously more constant than that of summer or of autumn. Two factors seem important to the relative constancy of spring production-the effective soil water recharge that occurs almost every winter and the inherent rhythm of growth of late spring-flowering ryegrass.

\section{ANNUAL VARIATION AT LINCOLN}

How much does pasture production vary with pasture age? High cool season yield is expected from new autumnsown pastures. Evidence is accumulating at Lincoln that clover-based pastures tend to decline in yield after the second or third full year. The phenomenon appears to be 
in part attributable to the clover base. Figure 2 illustrates the influence of age on clover production when white and red clovers have been sown as a mixture alone or with grasses in an experiment with three replicates in time. Clover production was significantly higher when sown without grass than when sown with each of the three grasses studied. Clover production declined significantly with age from the second to the fourth year. This dedine was independent of sowing mixture. The deficiency of clover production in the first full year may be outweighed by new grass but later decline in clover production is often associated with a decline in grass vigour.

A part from the influence of pasture age itself, herbage production from pastures may vary from year to year because of variations in weather conditions. A study of the relationships between pasture production and precipitation has been begun at Lincoln. Preliminary results indicate that the season of rainfall is a matter of some importance to annual yield. For the study of clover-based pastures at Lincoln, records were available for Wakanui soils from 12 years of pastures in which Ruanui ryegrass and Huia white clover were co-dominant. When' annual

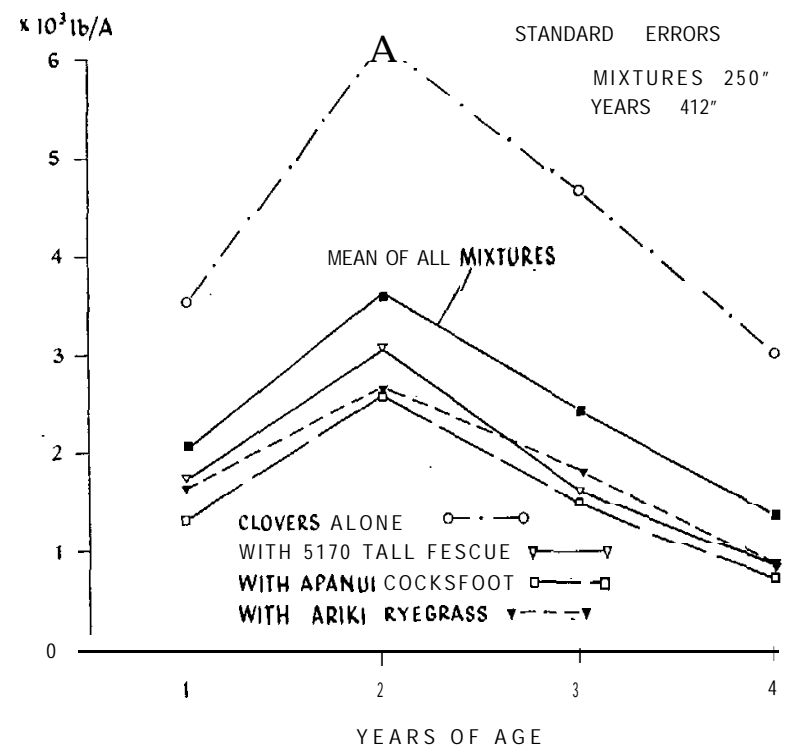

Fig. 2: Influence of pasture age on clover yield from pastures at Lincoln of Huia and Turoa clovers sown with and without grasses. 

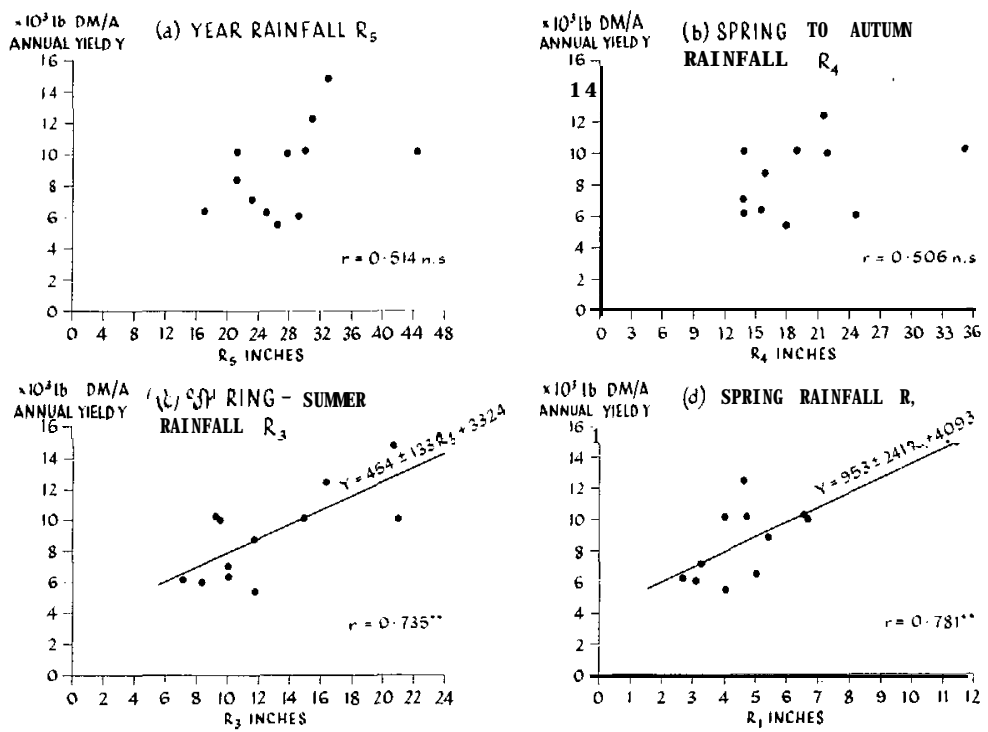

FIG. 3: Relationships of seasonal rainfall and annual yield of Ruanui ryegrass-Huia white clover pastures at Lincoln.

(September-August) pasture yield is plotted against annual (June-May) precipitation (Fig. 3a) the correlation is poor $(r=0.514$ n.s.). If the rainfall of the preceding winter is omitted (Fig. 3b) the correlation remains poor ( $r=0.506$ n.s.). If autumn rainfall is also omitted (Fig. 3c) there is a close correlation $\left(r=0.735^{* *}\right)$. This suggests that there may be considerable wastage. of autumn and winter rainfall above that used for cool season growth and soil water recharge. About $54 \%$ of the variation in annual pasture yield is accounted for by variation in rainfall for the spring-summer period from September to February. Summer rainfall alone is poorly correlated with annual herbage production ( $r=0.514$ n.s.) but spring rainfall is closely correlated with annual pasture yield ( $r=$ $0.781^{\prime \prime \prime}$ ) as shown in Fig. 3d. Sixty-one per cent. of variation in annual pasture yield is accounted for by variation in September to November rainfall. In practical terms, within the limitations illustrated, each additonal inch of spring rainfall means $950 \mathrm{lb}$ more herbage dry matter per acre in annual yield. A not dissimilar relationship 
between annual yield and spring rainfall is illustrated for A riki ryegrass-white clover pastures at Lincoln in Fig. 4.

One might ask if this importance of spring rainfall is not merely a reflection of the large contribution of spring herbage to annual yield. The correlation between spring rainfall and spring herbage production of Ruanui ryegrassclover pastures ( $r=0.585 \%)$ is not close. Variation in spring rainfall accounts for only $34 \%$ of variation in spring yield. The after-effects of spring rainfall may be as important as its current effects. Summer pasture yield is correlated with spring rainfall $\left(r-0.731^{\prime \prime \prime}\right)$ as well as with summer rainfall $\left(r=0.671^{*}\right)$. The multiple regression, $S_{2}=-401+$ (314 \pm 125$) R_{1}+(191 \pm 96) R_{2}$ accounts for $68 \%$ of the variations in summer yield $\left(S_{2}\right) . R_{1}$ and $R_{2}$ are spring and summer rainfall, respectively. Efforts to understand these after-effects of spring rainfall might well examine the influence of water stress before. grass flowering on aftermath. vigour and the effects of water stress on nitrogen fixation and 'on clover growth and survival.

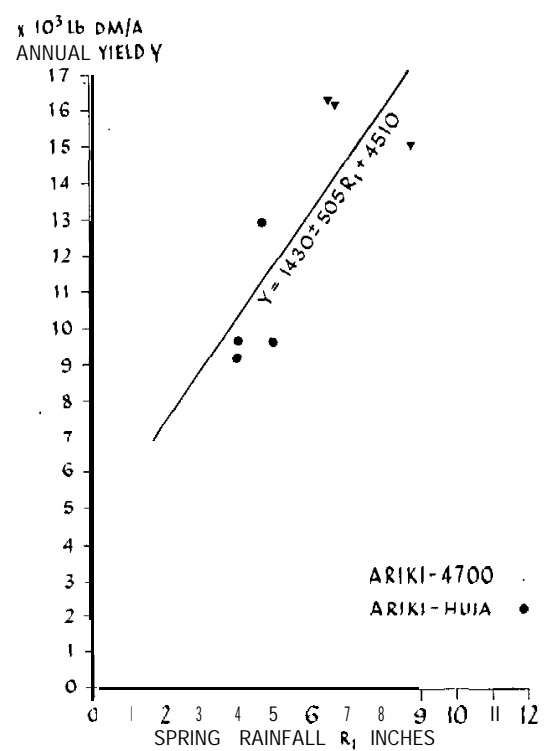

FIG. 4: Relationship of spring rainfall and annual yield of Ariki ryegrass . white clover pastures at Lincoln 


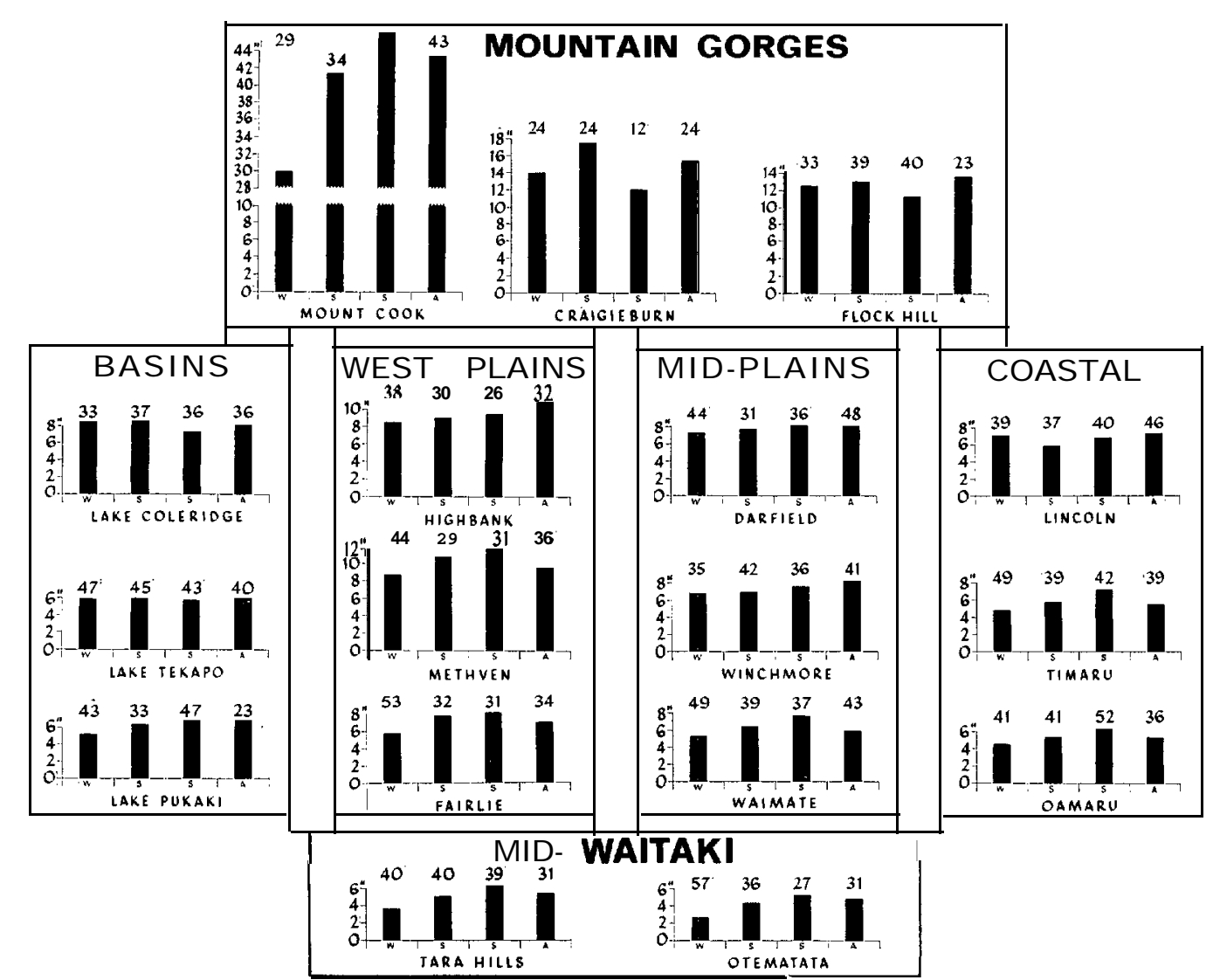




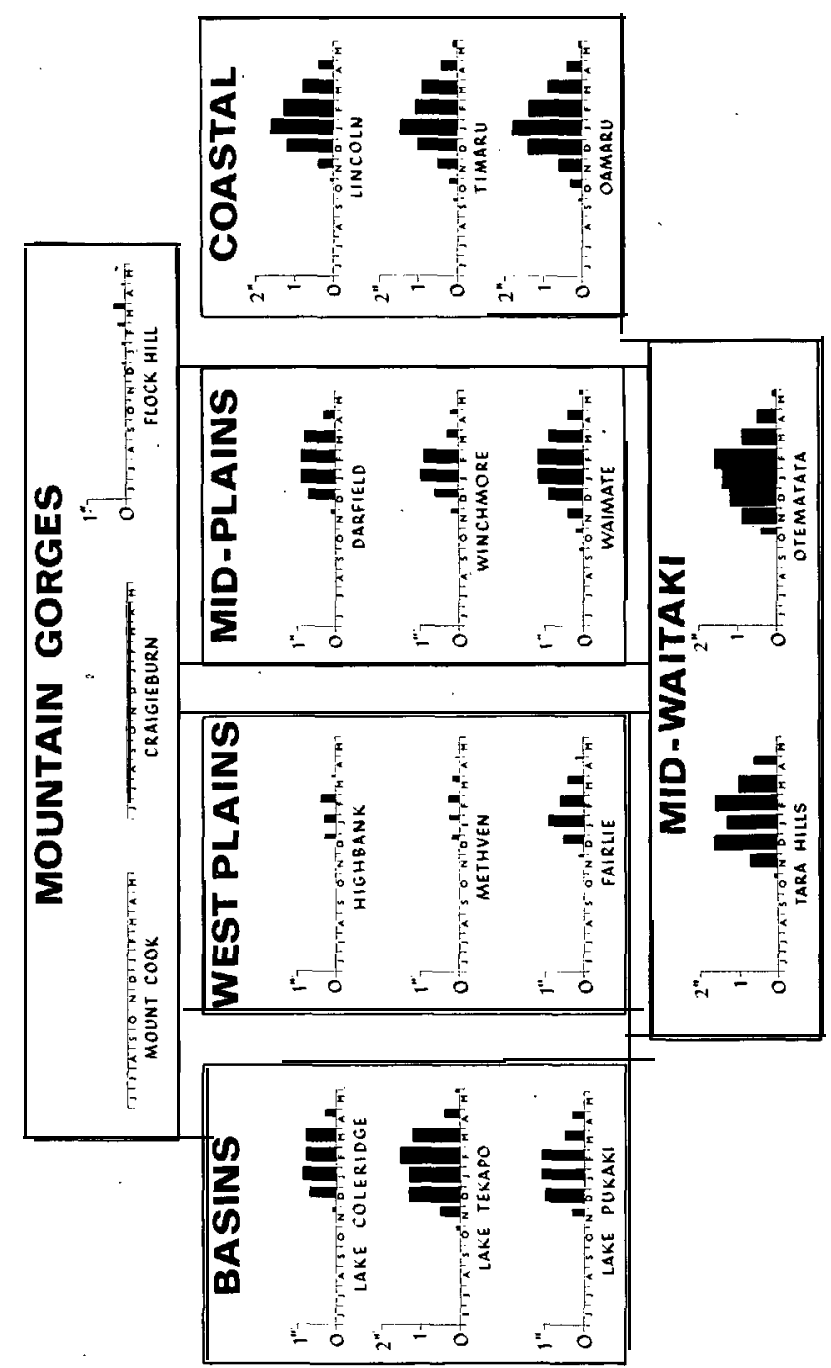

Fig. 6: Monthly water deficits at typical Canterbury and North Otago stations for soils with storage equal to 2 in. Height of columns indicates average deficit amount. Width of columns indicates percentage frequency of deficit occurrence. 
Annual Variation at Other Locations

Not all parts of Canterbury and North Otago have climates similar to that at Lincoln. Figure 5 presents a regional view of seasonal rainfall and its variability. The high seasonal rainfall of the mountain gorges in the northwest is contrasted with the low precipitation in the midWaitaki. Inland across the plains from the east coast there is an increase in precipitation. The inland basins, however, have less rain than the western plains. For most stations illustrated, the coefficient of variation for seasonal rainfall is between 30 and $50 \%$. In contrast with the fairly even seasonal rainfall distributions in Fig. 5, Fig. 6 indicates the different patterns of monthly water deficits for the same stations for soils with storage equal to two inches. This is part of a broad survey (Coulter, 1966) of water deficiency in New Zealand, based on simplified water balance using monthly rainfall totals and average potential evapotranspiration. Detailed comparisons between stations are not valid by this method but the broad
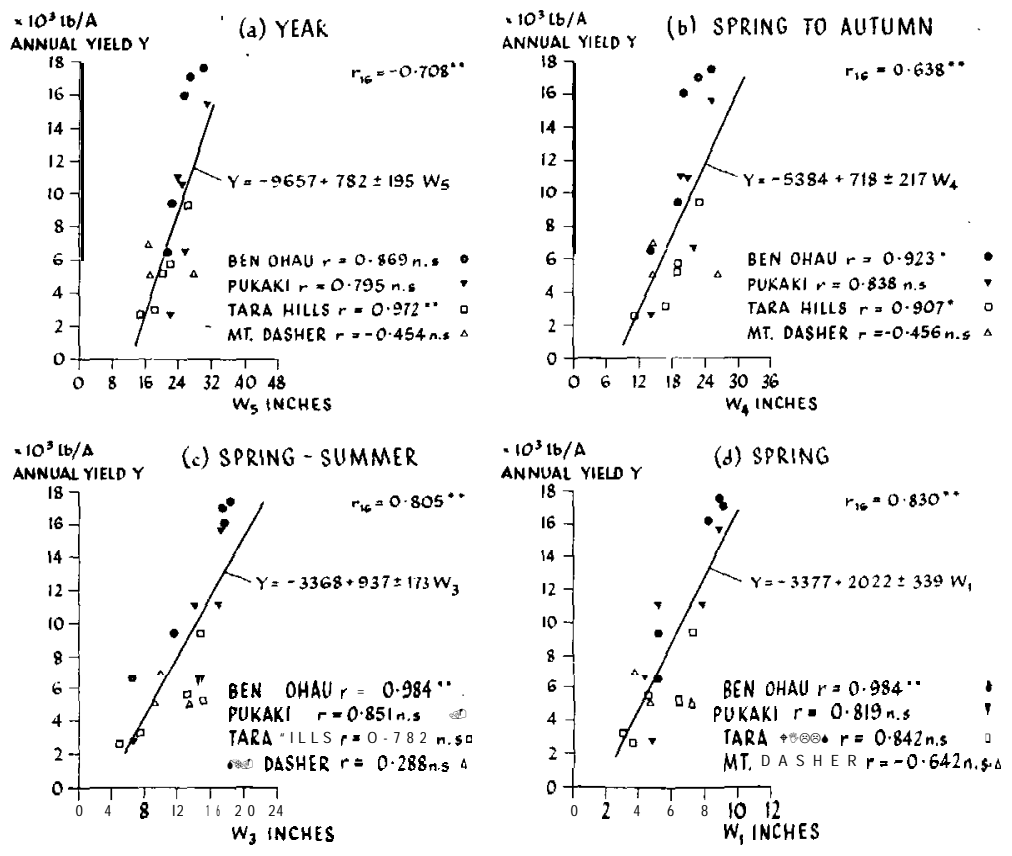

FIG. 7: Relationships of seasonal water supply and annual yield of cloveroversown tussock grassland pastures in lower montane sub-humid areas. 
regional character of water deficiency is illustrated for typical stations by the height of monthly columns (average deficit amount) and by width of columns (percentage frequency of occurrence of deficits). Soil moisture deficits are not serious in the mountain gorges or on the western plains. They are more serious, especially from December to March, on the coastal plains and in the mid-Waitaki.

Experiments in tussock grassland areas, especially those of O'Connor and Clifford (1966), offer the opportunity of examining the relationship between seasonal water supply and pasture production at different locations typical of subhumid areas of the inland basins and mid-Wa'itaki and of humid areas of the mountain gorges. Records of herbage production have been used where there is some confidence that previous experimental treatment has corrected maior soil fertility deficiencies. In sub-humid areas of tussock grasslands in the lower montane zone a total of 18 such records are available from four different sites. Rainfall records have been obtained from the nearest gauging station. At one site, Ben Ohau, allowance at the rate of $0.5 \mathrm{in}$. per month has also been made for observed seasonal inflow of ground-water. Correlation, coefficients between annual yield and seasonal water supply for different sites are presented in Fig. 7. Overall annual yield is correlated with annual water supply, with spring to autumn water supply, with spring-summer water supply, and with spring water supnly. Variation in spring water supply alone accounts for $69 \%$ of variatipn in annual
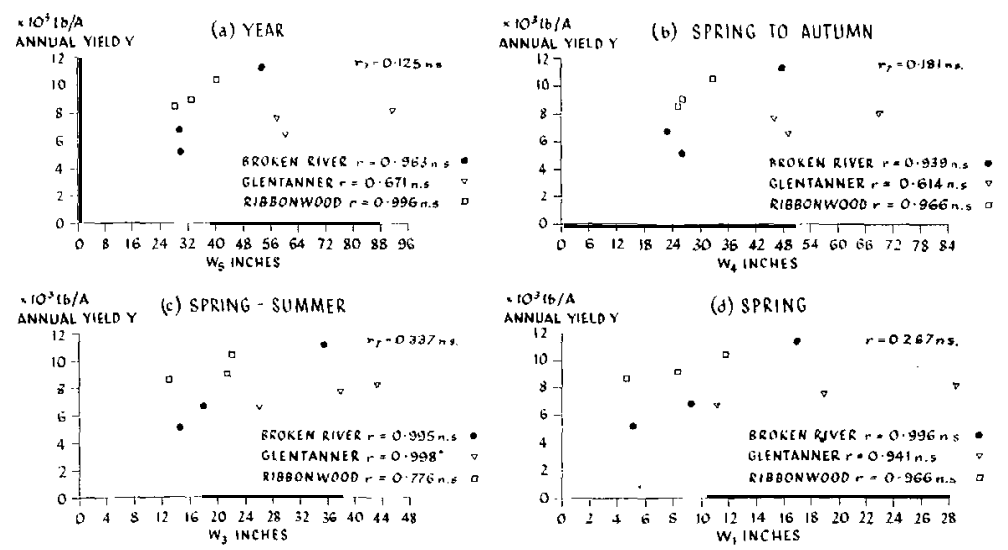

FIG. 8: Relationships of seasonal water supply and annual yield of clover. based pastures in upper montane humid areas. 
yield. In this zone the bulk of production occurs during spring and summer. Spring water supply and summer water supply are significantly correlated $\left(r=0.517^{*}\right)$ over this range of sites, so caution is needed in interpreting the role of seasonal water. However, spring water supply and spring herbage production are correlated $\left(r=0.626^{\prime \prime \prime}\right)$. Moreover, summer herbage yield is closely correlated $(r=$ $0.821^{* *}$ ) with spring water supply but is not closely correlated ( $r=0.568^{*}$ ) with summer water supply. It may be concluded that spring water supply has a dominant role in influencing annual herbage yield from these cloveroversown wild grass pastures.

In humid areas in the upper montane zone, year-to-year variations in precipitation have little effect on annual yield, as indicated in Fig. 8.

\section{LUCERNE-BASED PASTURES}

Seasonal Variation at Lincoln

Figure 9 presents the pattern of seasonal herbage production from lucerne and lucerne-cocksfoot pastures, grazed at preflowering stage, on Wakanui soils. The low winter production is included with either autumn or spring yield. Whereas spring yield is the largest and most constant component of yield of ryegrass-clover pastures,

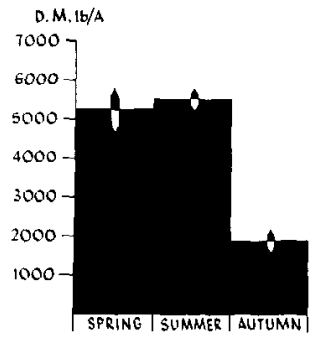

C.V. $289 \% \quad 11.8 \% \quad 318 \%$

MEAN

LUCERNE ALONE

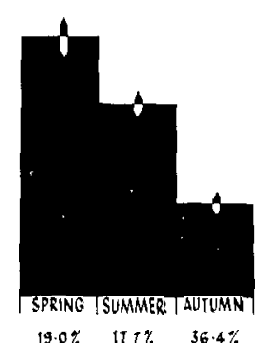

LUCERNE-COCKSFOOT

13,960 Ib/A D. M.

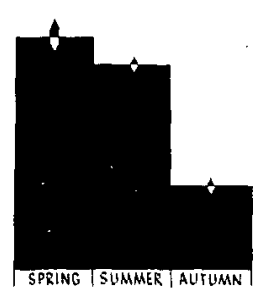

$26.5 \% \quad 13.2 \% \quad 36.4 \%$

ALL

$13,175 \pm 561$ lb/A D.M.

ANNUAL
YIELD

FIG. 9: Mean seasonal herbage yield at Lincoln from pastures of Wairau lucerne (eight years) and lucerne-cocksfoot (six years) when grazed at preflowering stage, within period 1951-68. Standard errors for seasons are indicated. 
spring yield of lucerne is more variable than summer yield. Inclusion of cocksfoot increases spring yield and makes it more reliable. Autumn yields of lucerne are similiar to those of ryegrass-clover pastures but have less variation. Annual herbage yields under preflowering grazing regimes have been nearly $50 \%$ higher than Ruanui ryegrass-clover pastures and less variable. Substantial further increase in herbage production may be obtained by delaying grazing of lucerne-grass pastures until the $10 \%$ bloom stage. This is shown (Fig. 10) from the yields in the Second year of differential grazing treatment of lucerne-grass associations established by overdrilling. Whereas under a preflowering grazing regime, yields averaged about 15,000 Ib D.M./acre, under a 10\% flowering grazing regime, yields averaged nearly 25,000 lb D.M./ acre for the nine months' period.

annual Variation at lincoln

No overall significant relationship has been established between seasonal or total rainfall and annual yield of lucerne-based pastures at Lincoln on Wakanui soils (Fig. 11). Summer yield of pure lucerne is correlated ( $r=$ $0.862^{* *}$ ) with summer rainfall. Autumn yield is correlated

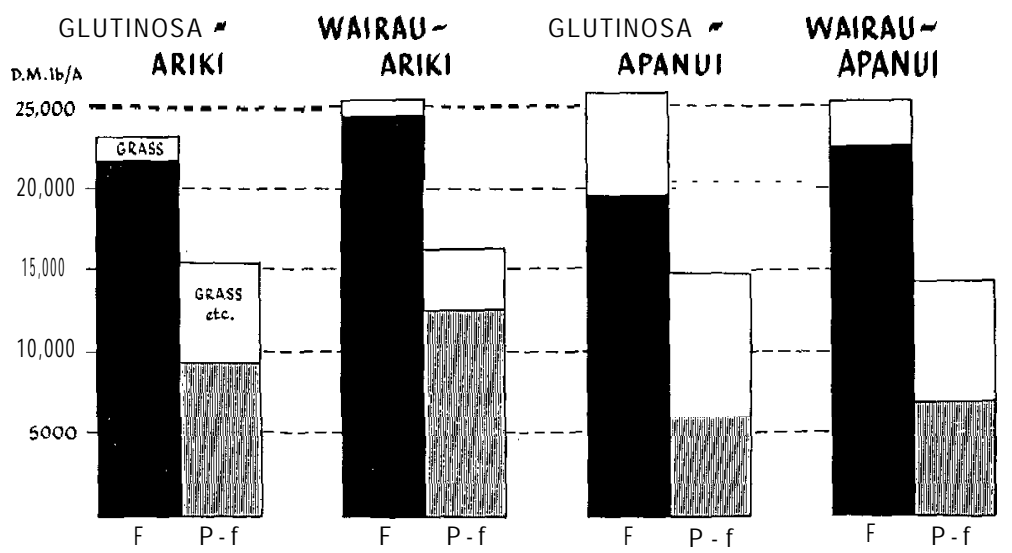

FIG. 10: Influence of sfuge of gath of lucerne at grazing on annual production of lucerne and of all herbage from lucerne grass associations on Wakanui soil at Lincoln, September, 1967 - June, 1968. Stages of growth are indicated, $10 \%$ flowering $(F)$ and preflowering $(P-f)$. Shaded portions of columns indicate lucerne yield. 

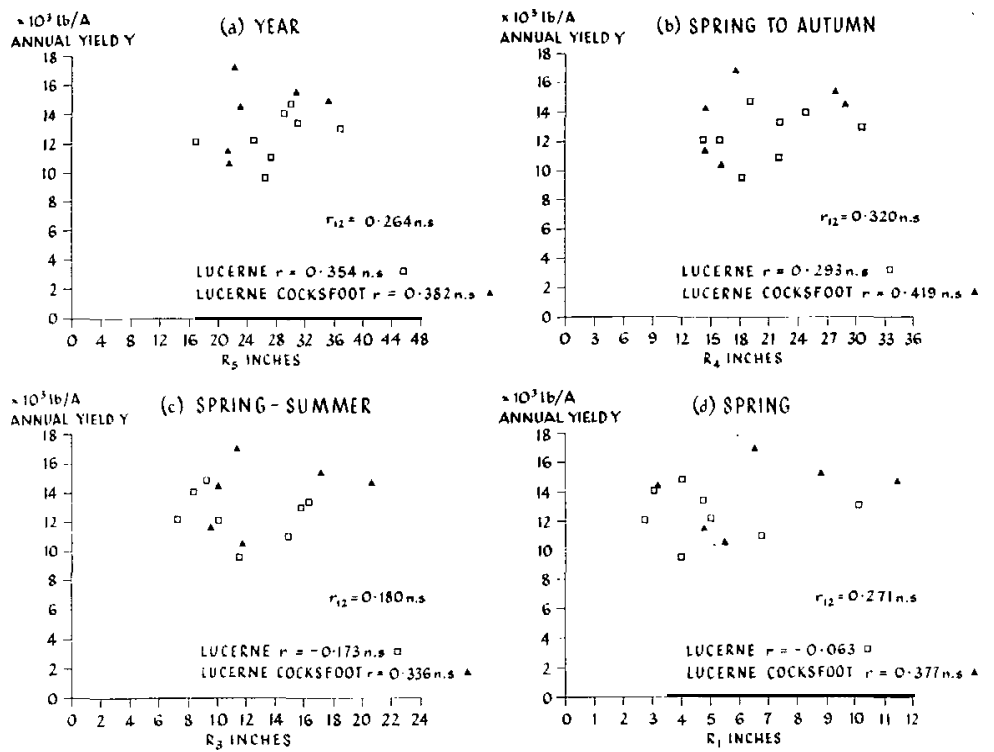

FIG. 11: Relationships of seasonal rainfall and annual yield of Wairau lucerne-based pastures on Wakanui soils at Lincoln.

( $r=0.844^{* *}$ ) with summer-autumn rainfall. The weather record will need to be searched more deeply to account for other variations that do occur.

\section{ANNUAL VARIaTION on Light Lands}

On shallow or stony soils such as the Lismore soil at Winchmore or the Eyre soil at Ashley Dene, seasonal rainfall influences annual yield of lucerne as shown in Fig. 12. Annual yield is not correlated with whole year's rainfall (Fig. 12a). Progressive omission of winter and autumn rainfall (Figs. $12 \mathrm{~b}$ and $12 \mathrm{c}$ ) improves correlation. Variations in spring rainfall account for $41 \%$ of variation in annual yield (Fig. 12d). Inclusion of summer rainfall in addition, as in Fig. 12c, accounts for $69 \%$ of variation in annual yield, Likewise, $69 \%$ of variation in annual yield is accounted for by inclusion of summer rainfall in a multiple re gression $Y=740+(566 \pm 174) R_{1}+(481 \pm 160) R_{2}$ where $R_{1}$ and $R_{2}$ are spring and summer rainfall, respectively. From this it may be concluded that, for annual yield of lucerne on light lands, spring and summer rainfall are of approximately equal value. 

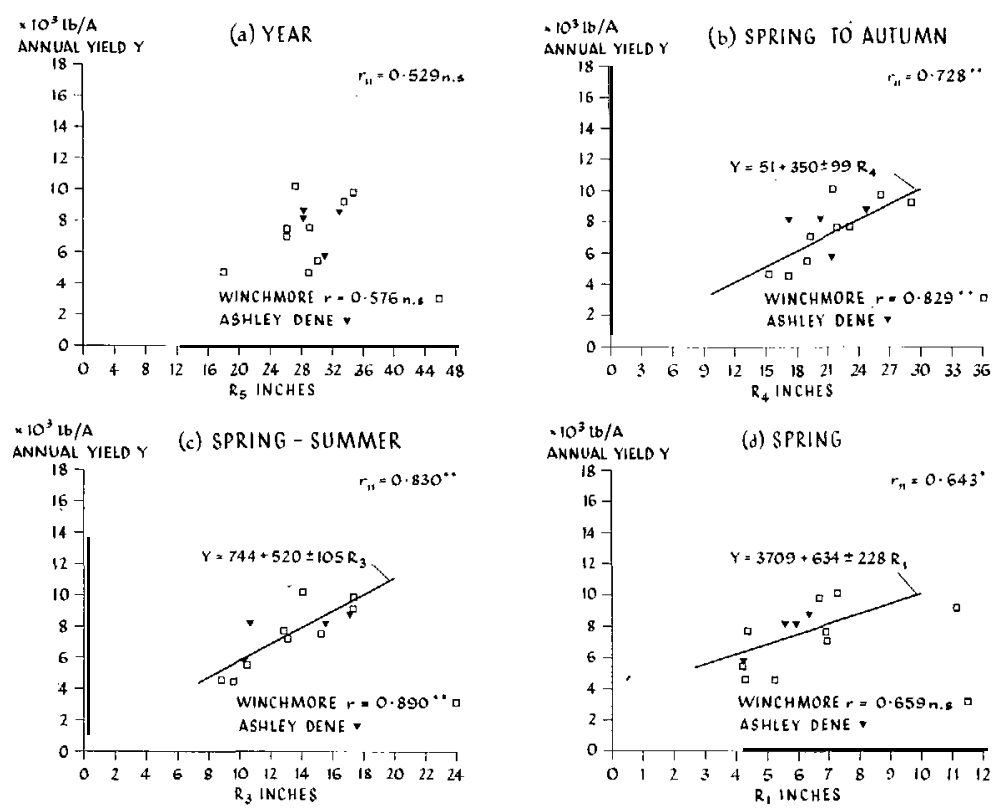

Fig. 12: Relationships of seusonal rainfall and annual yield of $W$ airau lucerne pastures on light lands at Winchmore and A shley D ene.

\section{CONCLUSION}

The important features of clover-based and lucernebased pastures in Canterbury and North Otago which have been demonstrated are :

(1) Clover-based pastures on deep soils at Lincoln are highly variable in yield, especially in summer, autumn and winter. Annual yield is highly dependent on spring rainfall. For clover-oversown pastures in the subhumid lower montane zone, there is a similar dependence of annual herbage yield on spring rainfall. Spring rainfall has after-effects on yield as well as its effects on current spring production.

(2) Lucerne-based pastures on deep soils at Lincoln are less variable in yield than clover-based pastures, especially in summer and autumn. Yields are not closely dependent on rainfall except for late summer and autumn yield of pure lucerne. Lucerne-grass associations on Wakanui soils are more constant in 
spring yield than pure lucerne and show outstanding annual yield responses to improved grazing management: On light lands, lucerne yield is highly dependent on spring and summer rainfall.

\section{ACKNOWLEDGEMENTS}

W. G. Thurston and Dr B. R. Watkin made available experimental records From Grasslands Division, D.S.I.R., Lincoln. The late C. E. Iversen and T. Ellis supplied lucerne records from Ashley Dene. W. R. Lobb and staff of Department of Agriculture supplied dryland lucerne records from Winchmore. Miss E. Stevenson, Applied Mathematics Laboratory, D.S.I.R., carried out all statistical analyses and K. R. West and Miss J. Anderson, Botany Division, D.S.I.R., prepared the illustrations.

\section{REFERENCES}

Brougham, R. W. 1959: N.Z. J. agric. Res., 2: 283-96.

Campbell, A. G. 1964: Proc. N.z. Soc. Anim. Prod., 24: 17-28.

Coulter, J. D. 1966: Proc. N.Z. ecol. Soc., 13: 4-8.

Mitchell, K. J. 1956: Proc. 7th int. Grassl. Cong.: 58-67.

O'Connor, K .F.; Clifford, P. T. 1966: Tus. Grassl. \& Mtn. Lands Inst. Rev., 11: 46-9.

O'Connor, K. F.; Vartha, E. W. 1969: N.Z. agric. Sci.: In press.

Rickard, D. S., 1968: Proc. N.Z. Grassl. Ass., 30: 81-93.

\section{DISCUSSION}

Seasons were defined as September to November, denoting spring, December to February summer, March to May autumn, and June to August as winter. Asked whether the comparisons between lucerne alone and lucerne plus grass were derived from one trial, O'Connor stated that the mean average yields for lucerne were from eight years and for lucerne plus cocksfoot six years, some common. He felt that a more reliable spring production would be obtained from a lucerne-grass association. Perhaps where good spring production was required the over-drilling of the lucerne crop with an annual ryegrass or cereal to give cool season growth should be practised.

In reply to a question on the effect of including temperature figures in his correlations, O'Connor considered that, at present, it was simpler to use rainfall figures. It would be difficult to decide what to use for temperature-should it be mean, maximum, minimum? To a further suggestion that rainfall figures used were gross and may not be effective for plants, and that some use should be made of temperatures, O'Connor commented that the rain recorded should be similar to that falling on the plants and that they had measurements of rainfall but not nearly so many for temperature. It was considered prudent to make use of the records a $\mathrm{v}$ a i $1 \mathrm{a}$ b l e. 